A Journal of Culture, English Language, Teaching \& Literature ISSN 14143320 (Print), ISSN 2502-4914 (Online)

Vol. 17 No. 2; December 2017

Copyright () Soegijapranata Catholic University, Indonesia

Kwentong Pambata: An Interactive Storybook for Teaching Filipino Fables, Legends, Parables and Short Stories

${ }^{1}$ Marivic R. Mitschek, ${ }^{2}$ Maureen Joy M. Nolasco, ${ }^{3}$ Maria Cristina DC Pindot, and ${ }^{4}$ Romina J. Sy

Computer Studies Department College of Science and Computer Studies, De La Salle University Dasmariñas, Cavite, Philippines

email: ${ }^{1}$ mrmitschek@dlsud.edu.ph; ${ }^{2}$ jnolasco@dlsud.edu.ph;

${ }^{3}$ mcpindot@dlsud.edu.ph; ${ }^{4}$ rjsy@dlsud.edu.ph

Received: 12-10-2017 Accepted: 3-11-2017 Published: 21-12-2017 


\title{
Kwentong Pambata: Interactive Storybook for Filipino Fables, Legends, Parables and Short Stories
}

\author{
${ }^{1}$ Marivic R. Mitschek, ${ }^{2}$ Maureen Joy M. Nolasco, ${ }^{3}$ Maria \\ Cristina DC Pindot, and ${ }^{4}$ Romina J. Sy \\ 1'mrmitschek@dlsud.edu.ph; mjnolasco@dlsud.edu.ph; \\ ${ }^{3}$ mcpindot@dlsud.edu.ph; ${ }^{4}$ rjsy@dlsud.edu.ph \\ ${ }^{1,2,3,4}$ Computer Studies Department, College of Science and \\ Computer Studies, De La Salle University Dasmariñas, \\ Cavite, Philippines
}

\begin{abstract}
This paper focused on the development and evaluation of a mobile application in which children could interact, be entertained, and especially be educated at the same time. It was mainly designed for children, parents/guardians, and teachers as well. The interactive storybook which was created was different from those available in the market. Kwentong Pambata is a children's storybook application designed for Android devices that features Filipino legends, fables, parables and short stories designed for Filipino children and children all over the world. It portrays Filipino values, traditions and character which contains moral lesson at the end of each story that would educate children's view in life, their characters, moral uprightness, and values. It is a storybook which contains fun pictures, texts, and sounds that kids will truly enjoy. The goal of the study is to develop an Android application that children could interact, learn, read, be entertained, improve and develop children's imagination and comprehension skills at an early age, and to promote Filipino stories and moral values. Kwentong Pambata application was developed using ActionScript 3.0. and Adobe Flash CS5.5. The application has 3 different language translations such as Filipino, English, and Mandarin. The proponents used ADDIE model for the development of the application. After the development, the application was evaluated. The total number of 40 respondents which were selected through probability sampling is used for the evaluation process. The application was evaluated according to its Usability, Reliability, Efficiency and Graphical User Interface (GUI). The evaluation questionnaire showed that the application
\end{abstract}


140 Celt: A Journal of Culture, English Language Teaching \& Literature, Volume 17, Number 2, December 2017, pp. 139 - 153

was rated as very satisfactory with the help of the respondents and was improved throughout its revisions.

Key words: android, mobile, application, CAI, fables, storybook, software

\begin{abstract}
Abstrak: Makalah ini berfokus pada pengembangan dan evaluasi aplikasi mobile dimana anak-anak dapat berinteraksi, dihibur, dan terutama dididik pada saat bersamaan. Ini terutama dirancang untuk anak-anak, orang tua / wali, dan guru juga. Buku cerita interaktif yang dibuat berbeda dengan yang tersedia di pasaran. Kwentong Pambata adalah aplikasi buku cerita anak-anak yang dirancang untuk perangkat Android yang menampilkan legenda, dongeng, perumpamaan dan cerita pendek Filipina yang dirancang untuk anak-anak dan anak-anak Filipina di seluruh dunia. Ini menggambarkan nilai, tradisi, dan karakter Filipina yang berisi pelajaran moral di akhir setiap cerita yang akan mendidik pandangan anak-anak dalam kehidupan, karakter, kejujuran moral, dan nilai-nilai mereka. Ini adalah buku cerita yang berisi gambar, teks, dan suara yang menyenangkan yang benar-benar dinikmati anak-anak. Tujuan dari penelitian ini adalah untuk mengembangkan aplikasi Android agar anak-anak dapat berinteraksi, belajar, membaca, menghibur, memperbaiki dan mengembangkan kemampuan imajinasi dan pemahaman anak-anak di usia muda, dan untuk mempromosikan cerita dan nilai-nilai moral Filipina. Aplikasi Kwentong Pambata dikembangkan dengan menggunakan ActionScript 3.0. dan Adobe Flash CS5.5. Aplikasi ini memiliki 3 terjemahan bahasa yang berbeda seperti bahasa Filipina, Inggris, dan Mandarin. Para pendukung menggunakan model ADDIE untuk pengembangan aplikasi. Setelah pengembangan, aplikasi dievaluasi. Sebanyak 40 responden yang dipilih melalui probability sampling digunakan untuk proses evaluasi. Aplikasi dievaluasi sesuai dengan Usability, Reliability, Efficiency dan Graphical User Interface (GUI) nya. Kuesioner evaluasi menunjukkan bahwa aplikasi dinilai sangat memuaskan dengan bantuan responden dan diperbaiki sepanjang revisi.
\end{abstract}

Kata kunci: android, aplikasi digital, CAI, fabel, buku cerita, software

\title{
INTRODUCTION
}

It is important for children to have an access to an application that is suited for their age. An application that would make them learn, be creative and imaginative, and at the same time make learning fun for them. Kwentong 
Mistchek, M.R.,Nolasco,M.J.M.,Pindot,M.C.D.C.,\& Sy,R.J.,Kwentong Pambata: 141 Interactive Storybook for Filipino Fables, Legends, Parables \& Short Stories

Pambata is a children's storybook application designed for Android devices that features Filipino legends, fables, parables and short stories designed for Filipino children and children all over the world. It portrays Filipino values, traditions and character which have moral lessons that would educate children's view in life, their characters, moral uprightness, and values. It is an application that would surely make children feel the fun with their whole family especially with their parents since it is interactive and enjoyable. It is a storybook with fun pictures, texts, and sounds that kids will enjoy.

The world, as we know it, is contracting with the growth of mobile phone technology. Every day, the number of users is increasing, thereby, also changing are the facilities. This starts with regular handsets which the primary use as just for texting and making phone calls, mobility has changed the lives of people and have become a crucial part of it. Now, these gadgets have countless uses and can be used as a camera, music player, tablet personal computer, television, web browser and with these new technologies, fundamentally, new software such as operating systems are required.

The most widely used mobile phone software platform these days is Android. Android does a software bunch which comprise not only an operating system but also as middleware and key applications. The fact that Android has become a prime target for mobile malicious software is no secret. This fact is alarming to consumers, but it should also be just as troublesome for application developers. It is most commonly-targeted mobile operating system when it comes to malware (FullStop Solutions, 2012). "When a user allows your app to access some aspect of their phone, they're trusting you with it." - Larimer. Applications role are very important in the device development that embody maintenance, business, entertainment, weather, games, and multimedia entertainment.

Android has been one of the most widely used mobile operating system all over the world especially here in the Philippines (King, 2012). According to Smart Communications, Smartphone users said to rise sharply in 2012. Google's mobile operating system, Android, with a 300\% spike tallied the highest, BlackBerry operating system coming in second with 66\%, and Apple's iOS with $62 \%$. This only shows how wide Android is being used by the people.

Android has become a popular operating system because it is free, open source, and available for customization. Android has been available for free since its launch and the company who made it possible, Google, made it clear that it will still be free in the future. Manufacturers around the world adopted 
142 Celt: A Journal of Culture, English Language Teaching \& Literature, Volume 17, Number 2, December 2017, pp. 139 - 153

the said operating system for their low cost smartphones. Unlike its existing operating system counterparts available in the market which are protected by a lot of copyrights, Google chose Android be open to all. In doing so, many programmers from around the globe were able to develop applications, while keeping its liabilities to a minimum.

With more people pooling ideas into the system, more innovative ideas are included which helped Android the operating system of choice. Furthermore, device manufacturers have the freedom to modify the Android according to their needs. This flexibility and ease of use is much enjoyed by users because manufacturers are now able to modify anything and everything that they need to make an experience a satisfying one.

\section{LITERATURE REVIEW}

A. Animated folktales edutainment software to motivate socio-cultural awareness

According to N. A. M. Zin \& N. Y. M. Nasir (2007) swift development in the field of technology has influenced the landscape of education and entertainment. Instructions can now be conveyed using well designed interactive multimedia application software (which will fall under Edutainment). Instructional delivery through effective learning strategies such as storytelling through 2D or 3D animation, animated storybooks, simulation and digital games are just few examples of multimedia tools.

Edutainment (which means Educational entertainment) is designed to educate in order to keep children interested and engaged while learning. Mostly developed with an entertaining flair as well as documentaries aimed at adults that are either humorous or fascinating in their execution.

\section{B. Game-based mobile learning system for campus on android platform}

Mobile technologies could be applied on a number of devices, such as mobile phones, smartphones, PDAs, netbooks, tablet PCs and so on (Wang, L., Wang, X, Ju, Li, Q, Li, M. \& Zhang, 2011. The Google-led Android platform becomes a major application developer as its fascinating open-source software stack compared to other platforms, such as Apple. The system is applied in Android platform and the SDK used is Android 2.1. 
Mistchek, M.R.,Nolasco,M.J.M.,Pindot,M.C.D.C.,\& Sy,R.J.,Kwentong Pambata: 143 Interactive Storybook for Filipino Fables, Legends, Parables \& Short Stories

\section{Promoting the reading comprehension of Engineering freshmen students through an interactive approach of content-based materials}

Morales (2010) informs that the primary apprehensions of reading education which is to develop appropriate pedagogies that will suit the needs and encourage abilities of second language learners today. The study reveals that reading should be taught in a more interactive and communicative manner rather than the traditional approach. The study sought to test the effectiveness of a content-based interactive reading pedagogy to enable first year engineering students develop significant levels of reading comprehension of science texts and develop compensatory strategies to help in improving their attitude and motivation towards reading. The quasi-experimental approach was used in the study.

\section{METHODS}

This research uses a model often used for Instructional System Design (ISD), which is the ADDIE model that provides a step-by-step approach for designing a model. As can be seen in Figure 1, the ADDIE design model revolves around the five phases such as Analysis, Design, Development, Implementation, and Evaluation. It forms a roadmap for the entire teaching and learning events.

Figure: 1

ADDIE model

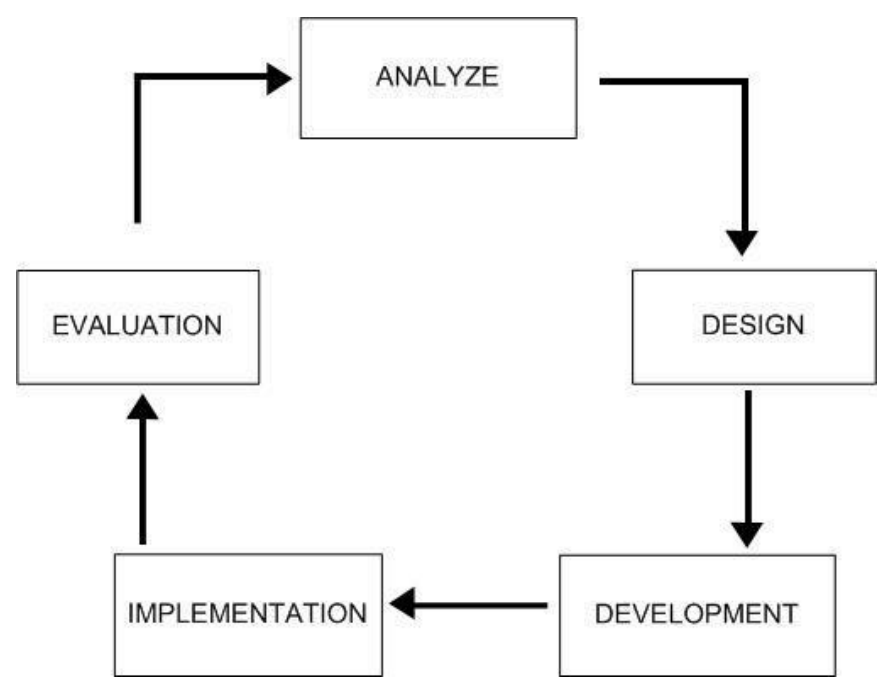


144 Celt: A Journal of Culture, English Language Teaching \& Literature, Volume 17, Number 2, December 2017, pp. 139 - 153

During analysis, the designer identified the problem, the goals, and objectives, the audience's needs, existing knowledge, and any other relevant characteristics. In designing, there is a systematic process of specifying learning objectives. In this phase, the design of the user interface such as controls and its content whereas images, audio and animation are included, the look and feel, graphic design and user interface were made as well as the content is determined. Development involves the actual creation or production of the content and learning materials based on the design phase made by the application developers.

During implementation, the plan is put in place and a technique for training the learner and teacher is developed. After delivery, the training materials are evaluated. In the evaluation, it consisted of tests designed for criterion-related referenced items to provide opportunities for feedback from the users.

This model was used for this study because it is appropriate for providing a means for decision making in order to determine who, what, when, where, why, and how of a learning program. It is suitable for learning aid and for training for a specific subject as well.

Figure 2:

IPO diagram

PROCESS

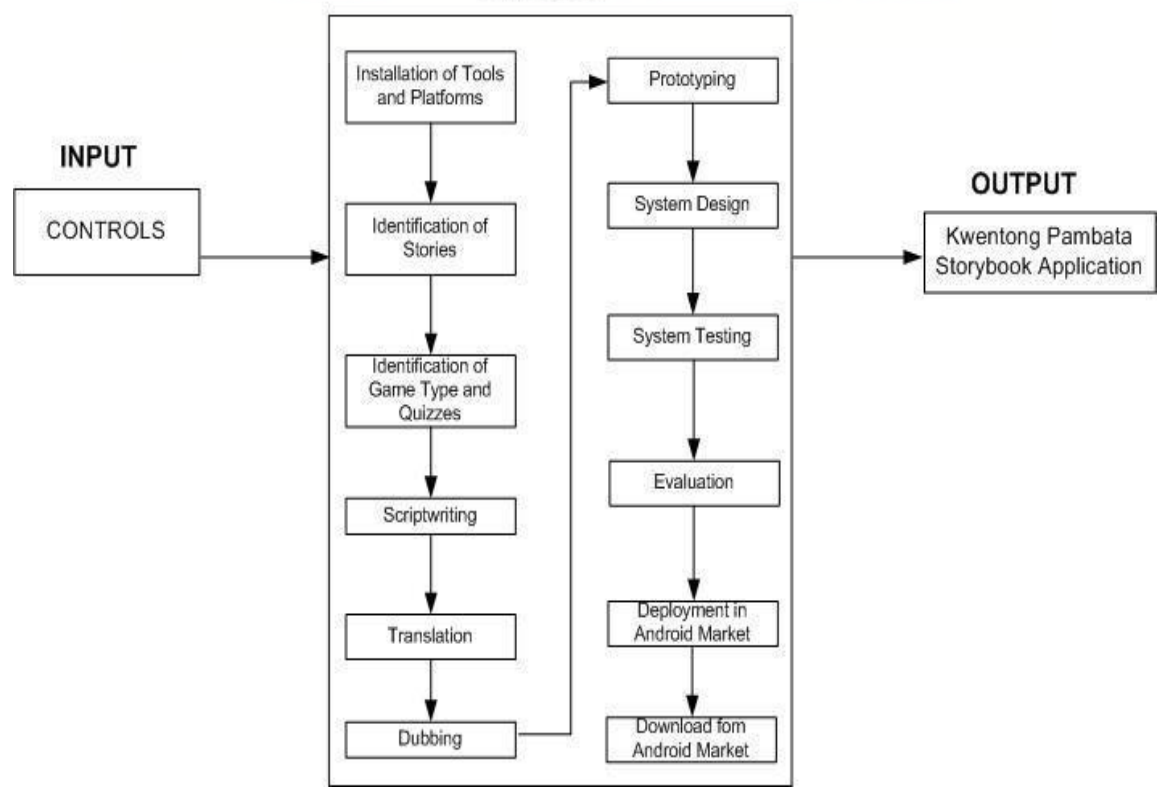


Mistchek, M.R.,Nolasco,M.J.M.,Pindot,M.C.D.C.,\& Sy,R.J.,Kwentong Pambata: 145 Interactive Storybook for Filipino Fables, Legends, Parables \& Short Stories

The IPO or Input-Process-Output diagram demonstrates the relationship between input and output elements that makes up the system and defines the processing steps that transform the input to output. It is a visual representation of the system's process that would provide a basic process knowledge needed to move forward with the project.

The different controls built in the application such as Language (options), Sound setting, Download books and Story are the inputs. Answers for the Quiz and the Game moves also serve as an input.

The language that is used in the story depends on the user's choice. The application supports three languages; English, Filipino, and Mandarin. When a user selects a language option, the story script and the menus will be in the chosen language. Sound setting is where the user can choose between Read It To Me which enables voice / dubbing and Read It Myself which disables voice / dubbing. Download books option provides access to download the books available from the market. The available books that can be downloaded are displayed in the book selection page (Library) with a -Get itll label. The downloaded book will then be added to the library. The Story selection is about selecting the story which the user wants to read. It will be retrieved from the database and the output will be the Story illustration which is composed of drawings, scripts, sound settings chosen, corresponding quiz, and corresponding game. The Answers for the quiz and the game moves will be a user input. The application will check if the answer for the quiz or the game move is correct or accurate. In the Quiz feature, the inputted answers will be checked and the correct answers will be counted. The output of the Quiz will be the remarks which are Poor, Fair, and Perfect that will be based on the number of correct answers. In the Game feature, if the user's move is correct or accurate, the user will get a sticker that signifies a perfect score / move, and if the user's move is not that accurate, $s /$ he will get a sticker that signifies an inaccurate score / move.

The installation of tools and platforms performed was for the development of the application. The proponents identified the stories that they would feature in the application for them to go on with the next processes such as identifying the game types and quizzes, and scriptwriting; which was translated and dubbed into three languages, and move to the next process which is Prototyping. System Design was done next using the controls as the input. The next process will be System Testing wherein the proponents tested and checked if all the functionalities specified were fulfilled by the system. The 
146 Celt: A Journal of Culture, English Language Teaching \& Literature, Volume 17, Number 2, December 2017, pp. 139 - 153

application was uploaded in the Android market so that users may be able download it.

\section{FINDINGS}

The total number of respondents is 40 which were selected through probability sampling. The evaluation questionnaire comprises of 4 major criteria in which the application could be evaluated. These criteria are usability, reliability, efficiency, and the graphical user interface. Each of these criteria would be discussed using tables and percentage results.

\section{A. Usability}

Usability can be defined as making applications and systems quick and easier to use, cultivate trust and easy to remember. It is a measure of an output's potential to accomplish the goals of the user effectively and efficiently.

Table 1:

\section{Usability of the application}

\begin{tabular}{lll}
\hline Usability Question & Weighted Mean & Remarks \\
\hline Easy to learn and use & 4.98 & Very Satisfied \\
\hline $\begin{array}{l}\text { The application developed is suitable for all } \\
\text { ages }\end{array}$ & 4.58 & Very Satisfied \\
\hline $\begin{array}{l}\text { The application can be used without } \\
\text { instructions }\end{array}$ & 4.35 & Satisfied \\
\hline $\begin{array}{l}\text { Storybooks are interesting to read because of } \\
\text { moral lessons, comprehensive questions and } \\
\text { mini games provided }\end{array}$ & 4.9 & Very Satisfied \\
\hline $\begin{array}{l}\text { The languages provided are written correctly } \\
\text { and clearly. }\end{array}$ & 4.98 & Very Satisfied \\
\hline \begin{tabular}{l} 
Overall mean \\
\hline
\end{tabular} & 4.758 & Very Satisfied \\
\hline
\end{tabular}

The respondents rated the application as very satisfactory with the overall mean for all the five questions in the survey form of 4.758. This means that the respondents find the application easy to use because it is suitable for all ages, they can understand it without the instructions because it was written correctly and clearly. 
Mistchek, M.R.,Nolasco,M.J.M.,Pindot,M.C.D.C.,\& Sy,R.J.,Kwentong Pambata: 147 Interactive Storybook for Filipino Fables, Legends, Parables \& Short Stories

\section{B. Reliability}

A good application must be operationally reliable. Reliability is simply the consistency of an application or system. One could consider the result reliable if one gets the same one repeatedly. In other words, reliability is the quality of an application or system to consistently perform its intended or required function or mission, on demand and without degradation or failure.

Table 2:

Reliability of the application

\begin{tabular}{lll}
\hline Reliability Questions & Weighted Mean & Remarks \\
\hline $\begin{array}{l}\text { The application functions without error or } \\
\text { problems }\end{array}$ & 4.45 & Satisfied \\
\hline $\begin{array}{l}\text { The supplied information from the application } \\
\text { is trustworthy }\end{array}$ & 4.7 & Very Satisfied \\
\hline $\begin{array}{l}\text { The application attained its Edutainment } \\
\text { (Educational - Entertainment) goal for the } \\
\text { users }\end{array}$ & 4.88 & Very Satisfied \\
\hline $\begin{array}{l}\text { The storybook application is recommendable to } \\
\text { others }\end{array}$ & 4.65 & Very Satisfied \\
\hline Overall mean & 4.67 & Very Satisfied \\
\hline
\end{tabular}

The application was rated 4.67 out of 5 which means that the respondents were very satisfied in terms of the application's reliability. This means that the application was able to run without error or problems, it was able to achieve its intended goals and it is very recommendable to others.

\section{Efficiency}

An application must possess efficiency. Efficiency is defined as performing tasks in an organized and capable way. It is the ability to function without waste of time and capable of achieving the desired result with the minimum use of resource or time.

Table 3:

Efficiency of the application

\begin{tabular}{lll}
\hline Efficiency Questions & Weighted Mean & Remarks \\
\hline $\begin{array}{l}\text { The application optimizes the speed and } \\
\text { memory requirements }\end{array}$ & 4.45 & Satisfied \\
\hline The developed application is efficient in doing & 4.5 & Very Satisfied \\
\hline
\end{tabular}


148 Celt: A Journal of Culture, English Language Teaching \& Literature, Volume 17, Number 2, December 2017, pp. 139 - 153

job for the parents who are guiding their children.

\begin{tabular}{lll}
\hline Overall mean & 4.525 & Very Satisfied \\
\hline
\end{tabular}

The application was rated as very satisfactory with a weighted mean of 4.525 by the respondents. In terms of its memory and speed requirements, the application was able to perform efficiently regardless of the device it was downloaded and installed, following the minimum hardware requirements.

\section{Graphical User Interface (GUI)}

Graphical User Interface is a type of user interface that allows users to interact with electronic devices using images rather than text commands. It represents the information and actions available to a user through graphical icons and visual indicators.

Table 4:

Graphical User Interface of the application

\begin{tabular}{lll}
\hline Graphical User Interface Questions & Weighted Mean & Remarks \\
\hline $\begin{array}{l}\text { The application portrays graphics and } \\
\text { interaction suitable for children of all ages. }\end{array}$ & 4.9 & Very Satisfied \\
\hline User-friendly & 4.95 & Very Satisfied \\
\hline Overall mean & 4.925 & Very Satisfied \\
\hline
\end{tabular}

The storybook contains a lot of animation and age-appropriate drawings and respondents found it very easy to use. This may be the reason that they rated the application as very satisfactory with a weighted mean of 4.925 .

\section{CONCLUSION}

Nowadays, many people have an access to different kinds of technology. Children in this generation are also engaged in such modern era of technology. It is important for them to have an access to an application that is suited for their age.

This is the reason for the creation of an application which is applicable for them and also for the parents / guardians and teachers. An Interactive Children's Storybook Android Application, Kwentong Pambata is the solution 
Mistchek, M.R.,Nolasco,M.J.M.,Pindot,M.C.D.C.,\& Sy,R.J.,Kwentong Pambata: 149 Interactive Storybook for Filipino Fables, Legends, Parables \& Short Stories

that features Filipino legends, fables, parables, and short stories designed for children all over the world. It portrays values, traditions, and character which have moral lessons that would educate children's view in life, their characters, moral uprightness and values, and surely children will find it fun as they do it with their whole family.

Since Filipino children these days are not familiar with our own legends and stories, the purpose of the study is to develop an Android application that children could interact, learn and develop their imagination, and comprehension skills at an early age, and to promote Filipino stories and moral values. These objectives were met and were able to gather relevant data and studies regarding the development of the said application. The above discussions have evaluated the applications' usage and features.

Through the research instruments and techniques and data gathering procedure, it was concluded that the application would help the parents, teachers, and especially the children in doing combination of educating and amusing oneself. The evaluation questionnaire showed that the application was rated as very satisfactory with the help of the respondents and was improved throughout its revisions.

\section{ACKNOWLEDGEMENT}

Parts of this paper have been presented at the $5^{\text {th }}$ Celt International Conference in Semarang, Indonesia during 9-11 ${ }^{\text {th }}$ September 2017. The conference was a project funded by the Ministry of Research, Technology, and Higher Education.

\section{REFERENCES}

Adobe. (2011). New mobile-ready features in Adobe Flash Professional CS5.5. Retrieved from http://www.adobe.com/inspirearchive/may2011/ articles/article6/index.html? trackingid=IOZGX

Amazines. (2013). Software Developing Android and iOS Games in the Philippines. Retrieved from http://www.amazines.com/Software/article_detail. $\mathrm{cfm} / 4503538$ ? articleid $=4503538$ 
150 Celt: A Journal of Culture, English Language Teaching \& Literature, Volume 17, Number 2, December 2017, pp. 139 - 153

Android App Market. (2012). Android Application Components. Retrieved from http://www.android-appmarket.com/android-applicationcomponents. html

Android Open Source Project. (n.d.). Android Platform Overview. Retrieved from http://source.android.com/source/overview.html

Android People (1966). Android People. Retrieved from http://www.androidpeople.com/hire-android-app-developer

Axelsson, A., Andersson, R., \& Gulz, A. (2016) Scaffolding Executive Function Capabilities via Play $\mathbb{E}$ Learn Software for Preschoolers. Retrieved from http://urn.kb.se/resolve?urn=urn:nbn:se:liu:diva-132531

Burnette, E. (2010). Hello, Android: Introducing Google's mobile development platform. Raleigh, N.C., Pragmatic Bookshelf.

Businesss Dictionary (1979). What is reliability? Retrieved from http://www.businessdictio nary.com/definition/reliability.html

Castillo, J. (2009). Probability Sampling and Randomization. Retrieved from http://explorable.com/probabiblity-sampling.html

Developers. (2017). Android Supported Media Formats. Retrieved from http://developer.android.com/guide/ appendix/media-formats.html

Developers. (2017). Android, the world's most popular mobile platform. Retrieved from http://developer.android.com/about/index.html

Developers. (2017). Animation and Graphics Overview. Retrieved from http://developer.android.com/guide/topics/graphics/overview.html

Developers. (2017). Application Fundamentals. Retrieved from http://developer.android.com/guide/components/fundamentals.html

Developers. (2017). UI Overview. Retrieved from http://developer. android.com/guide/ topics/ui/overview.html

Developers. (2017). Using Hardware Devices. Retrieved from http://developer.android.com/ tools/device.html

Mark, E. (2000). Android Application Development. Retrieved from http://android.ezinemark.com/android-application-development31831cd1e2a.html 
Mistchek, M.R.,Nolasco,M.J.M.,Pindot,M.C.D.C.,\& Sy,R.J.,Kwentong Pambata: 151 Interactive Storybook for Filipino Fables, Legends, Parables \& Short Stories

Mark, E. (2000). Exploring Android. Retrieved from http://android.ezinemark. com/exploring-android-7d3782ab6f08.html

Felker, D. (2011). Android application development for dummies. Hoboken: Wiley Publishing, Inc.

Game Developers Association of the Philippines. (2013). Skoolbo: What Learning Should Be?. Retrieved from http://www.gdap.org.ph/features/ skoolbowhat-learning-should-be/

Gargenta, M. (2011). Learning Android. Sebastopol: Calif, O'Reilly.

Grell, G. (2010). Introduction to Android Development. Retrieved from http://mobile.tutsplus.com/tutorials/android/introduction-toandroiddevelopment/

Holon Institute of Technology. (1970). HIPO. Retrieved from http://www.hit.ac.il/staff/ leonidm/information-systems/ch64.html

Huang, G. (2017). ActionScript 3.0 overview. Retrieved from http://www. adobe.com/devnet/actionscript/articles/actionscript3_overview.html

iTouch for Jailbreak. (2011). Android Application Development and Role of Mobile Apps Development Companies. Retrieved from http://itouchjailbreak. info/2011/07/android-applicationdevelopment-and-role-of-mobileappsdevelopment-companies/

King, R. (2012). Google engineers stress importance of Android app security at I/O.

Kyrnin, J. (2012). Flash Websites - Pros and Cons. Lifewire. Retrieved from http://webdesign.about.com/od/flash/i/flash_pros_cons_2.htm

Lawrence, S., Pennock, D. M., Flake, G. W., Krovetz, R., Coetzee, F. M., Glover, E., ... \& Giles, C. L. (2001). Persistence of Web References in Scientific Research. Computer. 34, 26-31. Retrieved from http://dx.doi.org/10.1109/2.901164.

Learning Theories. (2013). ADDIE Model. Retrieved from http://www.learning-theories.com/addie-model.html

Lee, W. M. (2011). Beginning Android tablet application development. Indianapolis, Indiana, Wiley Pub Publishing, Inc. 
152 Celt: A Journal of Culture, English Language Teaching \& Literature, Volume 17, Number 2, December 2017, pp. 139 - 153

Lim, R. (2012). Android has an 82.2\% Share of the Philippine Market. Mobile Raptor. Retrieved from http://mobileraptor.blogspot.com/2012/07/ android-has-822-share-of-philippine.html

Messina, V. (2010). FoodFight! Children's Book Review. Retrieved from http://www.androidrundown.com/app-rundown/food-fight-childrensbookreview/

Moock, C. (2007). Essential ActionScript 3.0. Sebastopol, CA, O'Reilly.

Morales, K. (2010). Promoting the reading comprehension of freshmen engineering students through an interactive approach to content-based materials. Philippine ESL Journal, 5.

Okan, Z. (2003). Edutainment: is learning at risk? Ph.D. University of Kent.

Open Handset Alliance. (n.d.). Android. Retrieved from http://www.openhandsetalliance.com/ android_overview.html

Philstar. (2013) From dual-SIM to dual-core, Cherry Mobile bares new Android devices. Retrieved from http://www.philstar.com/Article.aspx? articleId $=754346$

Rogers, R. (2009). Android application development. Sebastopol, Calif, O'Reilly.

Sansare, V. (2012). Gingerbread vs Ice Cream Sandwich Comparison - The ultimate Android showdown. Retrieved from http://www.thegeeksclub.com/ android-gingerbread-ice-cream-sandwich-comparison

Search SOA. (2013). What is usability? Retrieved from http://searchsoa.techtarget. com/definition/usability

Shupe, R. \& Rosser, Z. (2011). Learning Action Script 3.0. Sebastopol, CA, O'Reilly.

Skogberg, B. (2010). Android Application Development: A thesis in computer science department school of technology. Malmö University, Malmo, Sweden

Smith, J. (1999), One of Volvo's core values. Retrieved from http://www.volvo.com/environment/index.htm

Strunk, W., Jr., \& White, E. B. (1979). The elements of style (3 ${ }^{\text {rd }}$ ed.). New York: Macmillan. 
Mistchek, M.R.,Nolasco,M.J.M.,Pindot,M.C.D.C.,\& Sy,R.J.,Kwentong Pambata: 153 Interactive Storybook for Filipino Fables, Legends, Parables \& Short Stories

Social Compare. (2013) Android versions comparison. Retrieved from http://socialcompare.com/en/comparison/android-versions-compa rison

Talk Android. (2008). How to Develop Android Applications. Retrieved from http://www.talkandroid.com/guides/developer/google-androidapplicationguide/

Usability Net. (2006). What is Usability? Retrieved from http://www.usabilitynet. org/management/b_what.htm

Utah State University. (2004). Statistical Treatment of Data. Retrieved from http://ion.chem.usu.edu/ sbialkow/Classes/3600/Overheads/Stat Narrative/statistical.html

Van der Geer, J., Hanraads, J. A. J., \& Lupton R. A. (2000). The art of writing a scientific article. Journal of Scientific Communications, 163, 51-59.

Venture Beat. (2013). Apple iOS vs. Android consumer battle heats up (and BlackBerry gets crushed). Retrieved from http://venturebeat. com/2011/07/18/apple-ios-vs-android-os-consumer-battleheats-up-andblackberry-os-gets-crushed/

Wise Geek. (2003). What is Edutainment? Retrieved from http://www.wise geek.com/what-is-edutainment.htm

Zin, N. (2007). Edutainment Animated Folktales Software to Motivate SocioCultural Awareness. Undergraduate. Universiti Kebangsaan Malaysia. 